\title{
Ammonia Gas Removal using Biofilter
}

\author{
Kavyashree B A ${ }^{1}$, Ramya $N^{1}$, Sanjay Urs A $M^{1}$, Chandan K B ${ }^{1}$, Shilpa B $S^{2}$, Rashmi M B ${ }^{3}$ \\ Project Associates, Department of Environmental and Civil Engineering, Vidyavardhaka College of Engineering \\ Gokulam III stage, Mysuru ${ }^{1}$
}

Associate Professor, Department of Environmental and Civil Engineering, Vidyavardhaka College of Engineering,

Gokulam III stage, Mysuru²

Assistant Professor, Department of Environmental and Civil Engineering, Vidyavardhaka College of Engineering,

Gokulam III stage, Mysuru ${ }^{3}$

\begin{abstract}
Ammonia gas is emitted by many industries, poultry farms and composting plants, it is a colorless, toxic, reactive and corrosive gas with a sharp odor. Its abatement at source is essential as it is irritating to the skin, eyes, nose, throat, and lungs. Biofiltration is a new emerging technology that is being used as a control technique. The present work evaluates the use of a mixture of cattle manure and rice husk as biofilter media to reduce Ammonia gas. This study investigates the effective depth of filter media to reduce Ammonia gas. The Ammonia gas concentrations at Municipal Compost Plant were found to be $500-700 \mu \mathrm{g} / \mathrm{m}^{3}$. A bench scale biofilter column was designed and operated to investigate the removal of Ammonia gas in the Municipal Compost Plant. Removal efficiency for bed depth of 20 $\mathrm{cm}$ was found to be $61.5 \%$ and for bed depth of $40 \mathrm{~cm}$ was found to be $71.45 \%$. Nitrate concentration in biofilter media was initially $0.013 \mathrm{mg} / \mathrm{L}$ and at the end of $10^{\text {th }}$ day the concentration was rised to $0.022 \mathrm{mg} / \mathrm{L}$. It was observed that the Ammonia gas removal efficiency goes on increases as the accumulation of bacteria increases. Rice husk and cattle manure has been proved as an efficient media for removal of Ammonia gas from air stream.
\end{abstract}

Keywords: Ammonia gas, Biofiltration, Nitrate, Rice husk, Cattle manure.

\section{INTRODUCTION \& LITERATURE}

At present, solid waste management is becoming a global problem in developed countries. Composting is an environmentally friendly technology to treat and recycle organic wastes. Composting is not only used for the organic fraction of municipal solid wastes, but is also applied to residuals coming from industrial activities. Municipal or industrial wastewater sludge and animal byproducts are examples of organic solid wastes susceptible to composting. The problem of gaseous emissions can be approached from several points of view: occupational health and safety, olfactory nuisance, and atmospheric impact. Ammonia gas is released into the atmosphere from various sources, such as carcass-processing plants, sewage treatment plants, composting works, livestock farms and wastewater treatment plants. The emission can constitute a source of olfactory nuisance, and lead to nutrient enrichment and acidification of aquatic and terrestrial environments. At present, odor emissions and atmospheric pollution are the most common problems associated with composting of organic wastes in large scale facilities. Composting installations present numerous odor sources, including the reception and handling of materials, active composting, stock piling, etc. Exhaust gases from composting are usually characterized by high flow rates and low pollutant concentrations. Ammonia gas has received much attention as it can be easily identified from other composting odors, often represents the main nitrogen gas emitted during composting and it can be released in large amounts (Estela Pagans et al., 2005).

Ammonia gas is a colorless, toxic, reactive and corrosive gas with a very sharp odor. Ammonia gas is irritating to the eye and the respiratory tract and at high concentrations with acute overexposure, can lead to death within minutes. High concentrations of Ammonia gas kill most organisms. A number of compost and industrial facilities have been closed down because of their odors. Gaseous Ammonia gas is mainly generated by livestock farming, petrochemical industries, metal manufacturing plants, food, pulp, and paper industries, textile plants, waste treatment plants, and sludge processing and composting plants. Increasingly, stringent regulations for emissions have stimulated research to develop more efficient and cost effective control technologies. The traditional treatment such as activated carbon adsorption, wet scrubbing condensers and thermal oxidation which are generally expensive and produce secondary pollutants (Thaniya Kaosol et al., 2012).

Biofiltration has been used successfully in odour control and for the elimination of organic and inorganic pollutants in air from stationary sources. It is considered a clean technology, with low capital and operating cost, low energy requirements, and an absence of residual products requiring further treatment or disposal (Singh et al., 2002). The process is based on passing a contaminated stream of Ammonia gas through a microbial biofilm immobilized on a porous support. The pollutants diffuse from the gas into the thin layer of biofilm attached to the support media and are metabolized. The end products of the complete biodegradation are $\mathrm{CO}_{2}$, water and microbial biomass. The quality of the filter media has been reported as one of the key factors in biofilter performance. Compost-based media 
have been extensively used in recent years because they are cheap and have several microbial communities capable of degrading various pollutants. This research investigates the efficiency of a compost biofilter for the removal of Ammonia gas from the composting plant (Premkumar R. et al., 2013). The Objective of this research is to design biofilter for Ammonia gas removal in a Municipal Compost Plant.

\section{A. BIOFILTRATION OF AIR}

Air biofiltration has been practiced since the early decades of the last century and has gained much interest in recent years for controlling odorous emissions into the air, toxic compounds, and VOCs. The principle of biofiltration is relatively simple: a contaminated air stream is passed through a porous packed bed on which pollutant degrading cultures of microorganisms are immobilized, and air biotreatment relies on microbial reactions for the degradation of waste compounds. As the odorous and contaminated air passes through the media, the contaminants in the air stream are absorbed by the biofilm. These contaminants are then oxidized to produce biomass, $\mathrm{CO}_{2}, \mathrm{H}_{2} \mathrm{O}, \mathrm{NO}_{3}$, and $\mathrm{SO}_{4}$. Biofilter is commonly used to mitigate livestock emissions. It is a bioreactor filled with wet woodchips or composts that separates Ammonia gas from contaminated air streams through absorption, and then oxidizes it into nitrite and nitrate using microorganisms by that grow on the surface of packing media.

\section{B. PRINCIPLE OF BIOFILTRATION}

In this study, the Ammonia gas removal is evaluated by a laboratory-scale bio-filter using a mixture of manure fertilizer and rice husk as the bio-filter media. The Ammonia gas, before and after biofiltration were analyzed to determine the effect of the bio-filter on the removal efficiency. In the process of Ammonia biofiltration, microorganisms convert Ammonia to nitrate. This process is carried out by nitrifying microorganisms. Conversion of $\mathrm{NH}_{4}^{+}$to $\mathrm{NO}_{2}^{-}$is accomplished by nitrosomonas and nitrobacteria that convert $\mathrm{NO}_{2}{ }^{-}$to $\mathrm{NO}_{3}^{-}$.

The microbial population in the packing material is relatively inactive before contact with the Ammonia substrate. After the acclimation period has passed, the microorganisms grow in mass and number in the thin layer of water surrounding the support media of the bio-filter forming a biofilm. The pollutants diffuse from the gas phase into the biofilm where the microorganisms are immobilized and in which oxidation of Ammonia gas into harmless byproducts of $\mathrm{NO}_{2}^{-}, \mathrm{NO}_{3}{ }^{-}$occurs as shown in Figure 1 (Guillermo Baquerizo et al., 2005).

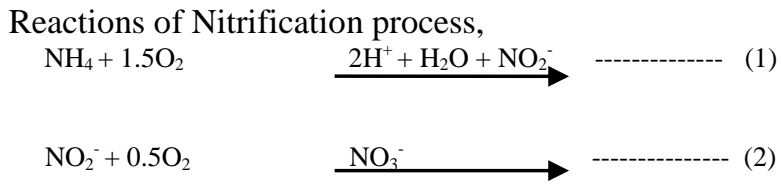

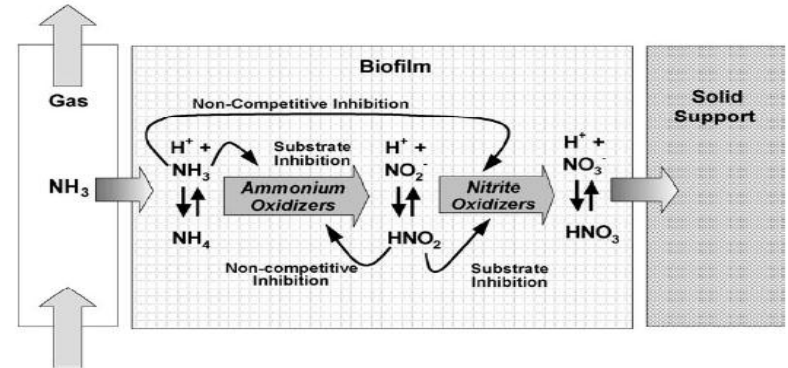

Figure 1 Schematic of the Nitrification Process (Guillermo Baquerizo et al., 2005)

When compared to other traditional methods such as activated carbon adsorption, wet scrubbing condensers and thermal oxidation which are generally expensive and produce secondary pollutants. Biofiltration is an efficient technique for removing Ammonia gas from composting plant. Biofiltration has received much attention due to high removal efficiency, low capital and operating costs, safe operating conditions, low energy consumption and it does not generate undesirable byproducts and converts many organic and inorganic compounds into harmless oxidation products (Thakur Prabhat Kumar et al., 2011).

\section{MATERIALS AND METHODOLOGY}

A. Study Area

Mysuru city is named as second cleanest city in 2010 by Nationwide Union Urban Development Ministry (NUUDM). Mysuru is one of the major cities in Karnataka producing nearly 600 tons of solid wastes every day. Nearly 200 tons of solid waste is treated at treatment plant at Vidhyaranyapuram daily to produce compost, remaining nearly about 400 tons of garbage dumped as untreated. These solid wastes are dumped for a period of six months on regular mixing. This creates anaerobic condition at the dumping site and results in bad odor and release of volatile organic compounds. The major VOCs released are Ammonia gas. The existing treatment plant was set up in Vidyaranyapuram in 1996, which produces unbearable stink emanating from these wastes proving a health hazard to the locals. Residents of JP Nagar, Vishveshwara Nagar and Vidyaranyapuram have been suffering from different ailments like nausea, eye infection, giddiness, headache and asthma. The existing treatment plant also burns plastic which emits bad smell and carbon dioxide. The existing treatment plant covers an area of 5 hectares (Basavarajappa H.T. et al., 2013).

In the present work, Ammonia gas was monitored at Municipal Compost Plant, Vidyaranyapuram, Mysuru. Municipal Compost Plant is located at the base of Chamundi hills as shown in Plate 1.

B. Monitoring and Determination of Ammonia gas Ammonia gas concentration was monitored using High Volume Air Sampler using sulphuric acid as absorbing solution for 8 hours at a flow rate of 1.5LPM. Ammonia gas concentration was determined by Indophenol method. In this method, standard curve for Ammonia gas is determined using Standard stock Ammonia solution $(1 \mathrm{ml}=1.22 \mathrm{mg} \mathrm{NH}$ ). To 
the standard stock solution add $1 \mathrm{ml}$ phenol solution, 1ddtermined using Hot air oven. The acclimatized filter media sodium nitroprusside and $2.5 \mathrm{ml}$ oxidizing solution. Allow forameters such as $\mathrm{pH}$ and nitrates were determined. Gravel of color development for $1 \mathrm{~h}$ and measure the absorbance at 6 stite $40 \mathrm{~mm}$ was used as supporting media and it also provides $\mathrm{nm}$ using Spectrophotometer. Prepare a standard curve free flow and uniform distribution of air.

plotting absorbance readings of standards against Ammonfatwo-bed layer biofilter was designed as shown in the Figure concentrations of standards. Prepare a blank and treat the The biofilter was constructed from a Poly Vinyl Chloride samples same as standards. Plate 2 shows monitoring pipe with a height of $550 \mathrm{~mm}$ and a diameter of $60 \mathrm{~mm}$.

Ammonia gas using High Volume Air Sampler at samplitige column of biofilter was packed with the mixture of cattle station.
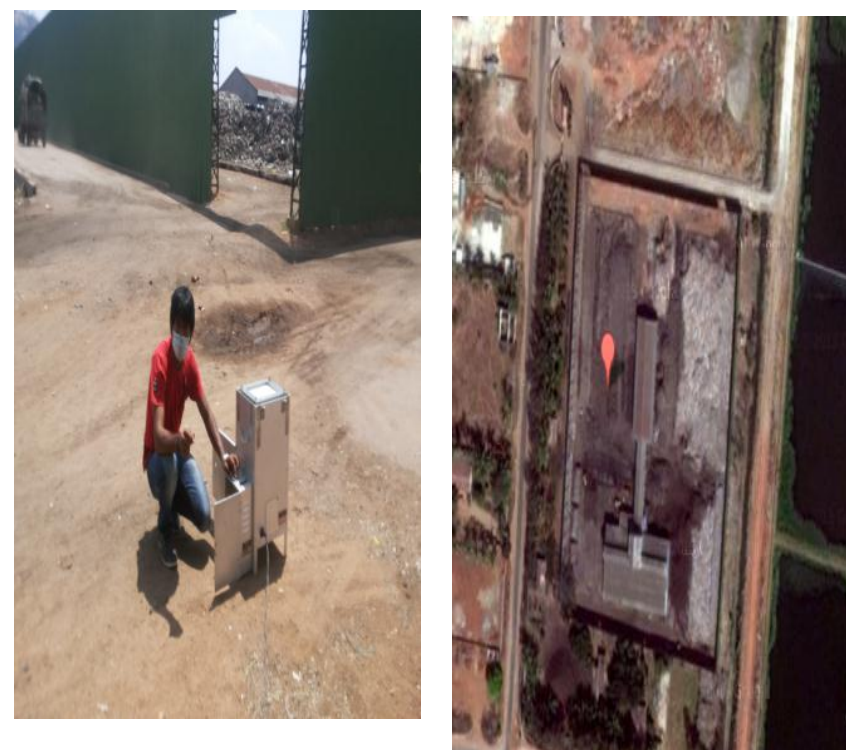

Plate 1: Monitoring and Location of sampling point [Source: Google map]

C. $\quad$ Materials used

Column specifications

○ Material: Poly Vinyl Chloride

Diameter: $60 \mathrm{~mm}$

Height of biofilter: $550 \mathrm{~mm}$

No of sampling ports: 3

Diameter of the port: $15 \mathrm{~mm}$

Filter Media specifications

Cattle manure

○ Rice husk - Grinded and size of $0.6 \mathrm{~mm}$ retained in the sieve

- Gravel - 40mm size

D. Designing and operation of biofilter

For biofilter media, the cattle manure was procured from Kumbara koppal, Mysuru. Cattle manure was selected as a filter media as it contains nitrate oxidizing bacteria such as nitrosomonas and nitrobacter. Rice husk was procured from Jwalamala Ricemill, Mysuru. Initial characteristics of cattle manure like $\mathrm{pH}$, nitrates were determined. Using Phenyl Disulphonic Acid and Ammonium hydroxide Nitrate was determined by measuring absorbance at $640 \mathrm{~nm}$ using spectrophotometer. Rice husk was grinded and size of $0.6 \mathrm{~mm}$ retained in the sieve was selected. Rice husk was soaked in the water for $24 \mathrm{hr}$. The cattle manure and soaked rice husk was mixed at a ratio of $1: 3$. The mixture was acclimatized for 10 days. Moisture content of acclimatized filter media was manure and rice husk as shown in Plate 3. The packed biofilter material in each layer was supported by a metal sieve plate. Gas-sampling ports were provided at the inlet and outlet of each layer. In addition, two media sampling ports were provided in each layer for taking samples from the packing material and the diameter of the sampling ports was $15 \mathrm{~mm}$. $5 \mathrm{ml}$ of nutrients was added to maintain moisture content in the biofilter on daily basis.

Air sample was made to pass through the filter media by connecting suction pump at the top of the biofilter. The air flow rate was measured using flow meter in LPM as shown in Plate 4 and was found to be 1.5 LPM using gas flow meter as shown in Plate 3. Outlet of the suction pump was connected with a pipe and was immersed in the absorbing solution. The inlet and outlet Ammonia gas concentration was determined using Indophenol method. Temperature, wind velocity and humidity data were collected for sampling days. The minimum temperature and maximum temperature during study period was found to be 32 and $39^{\circ} \mathrm{C}$. Humidity varied between 26 to $37 \%$ and wind speed varied between $11 \mathrm{~km} / \mathrm{hr}$ to $27 \mathrm{~km} / \mathrm{hr}$. Set up of biofilter at sampling station is shown in Plate 4 and Table 1 shows the National Ambient Air Quality Standards for Ammonia gas.

Empty Bed Retention Time (EBRT in seconds): The empty bed residence time is defined as the time the air is in contact with the biofilter media. It is calculated using the following formula:

$\mathrm{EBRT}=(\mathrm{Q} / \mathrm{V})$

Where, $Q=$ Flow rate of air/gas $\left(\mathrm{m}^{3} / \mathrm{s}\right)$ $\mathrm{V}=$ Volume of filter media $\left(\mathrm{m}^{3}\right)$

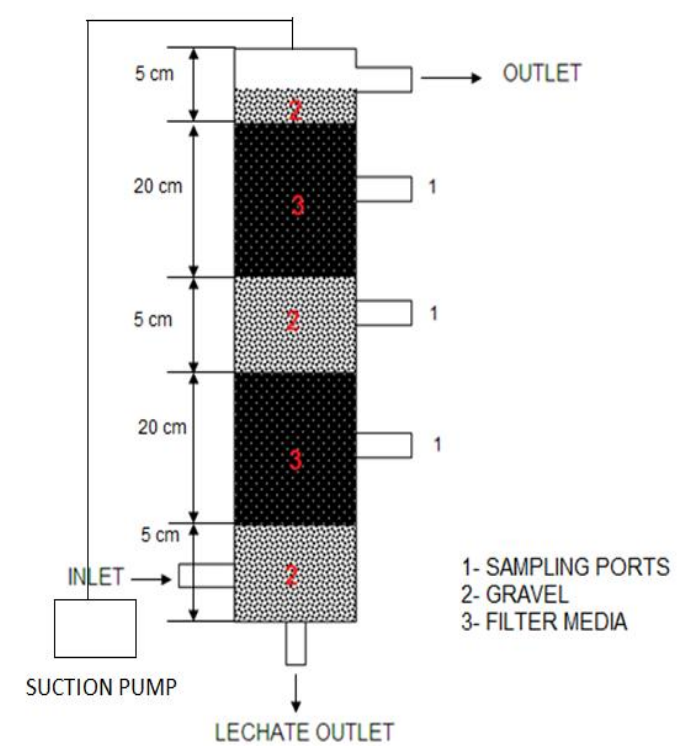

Figure 2: Schematic of Biofilter 


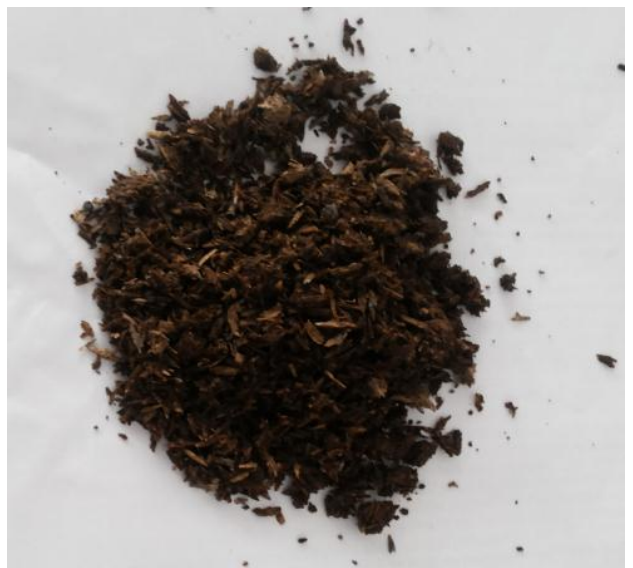

Plate 2: Cattle manure and rice husk mixture

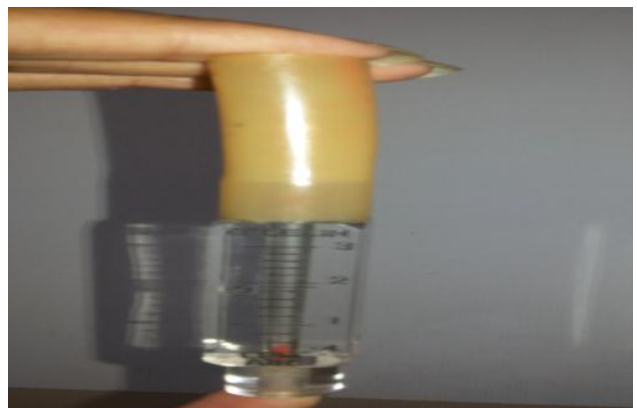

Plate 3: Flow meter for measuring air flow rate

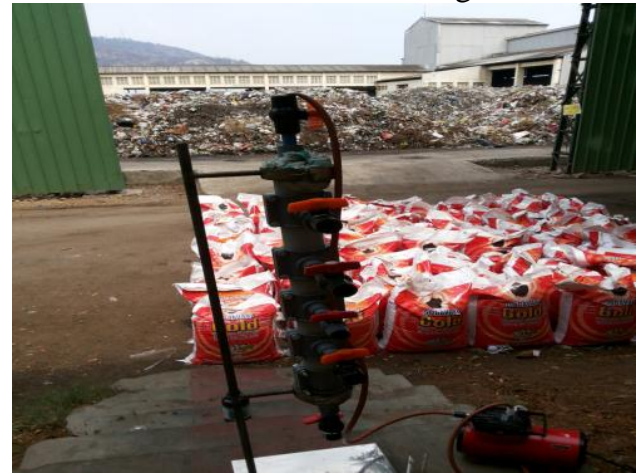

Plate 4: Setup of biofilter at sampling station

Table 1: National Ambient Air Quality Standards for Ammonia gas

\begin{tabular}{|l|l|l|l|}
\hline Pollutant & $\begin{array}{l}\text { Time } \\
\text { weighted } \\
\text { average }\end{array}$ & $\begin{array}{l}\text { Industrial, } \\
\text { Residential, } \\
\text { Rural and } \\
\text { other Areas }\end{array}$ & $\begin{array}{l}\text { Ecologic } \\
\text { ally } \\
\text { Sensitive } \\
\text { Area }\end{array}$ \\
\hline $\begin{array}{l}\text { Ammonia, } \\
\mu \mathrm{g} / \mathrm{m}^{3}\end{array}$ & Annual & 100 & 100 \\
$24 \mathrm{hr}$ & 400 & 100 \\
\hline
\end{tabular}

\section{RESULTS AND DISCUSSION}

\section{A. Characteristics of Bio-filter media}

The initial $\mathrm{pH}$ and nitrate concentration of cattle manure was found to be 8.5 and $0.0079 \mathrm{mg} / \mathrm{L}$ respectively. The moisture content increased from initial value of $40.4 \%$ to final value of $60.8 \%$ due to the absorption of moisture, $\mathrm{pH}$ increased from initial value of 8.5 to final value of 8.98 due to release of hydroxide ion during the nitrification process and the concentration of nitrate increased from initial value of $0.013 \mathrm{mg} / \mathrm{L}$ to final value of $0.022 \mathrm{mg} / \mathrm{L}$ due to the conversion of nitrites to nitrates by microorganisms. The Empty Bed Retention Time of biofilter was found to be 120 seconds.

\section{B. Bio-filter efficiency}

The Ammonia gas concentration at Municipal Compost Plant was found to be $500-700 \mu \mathrm{g} / \mathrm{m}^{3}$. Ammonia gas removal efficiency for bed depth of $20 \mathrm{~cm}$ was found to be $61.5 \%$ and for bed depth of $40 \mathrm{~cm}$ was found to be $71.45 \%$ as shown in Figures 3 and 4 . The removal efficiency goes on increases as the accumulation of bacteria increases.

The mixture of cattle manure and rice husk was found in the present study to be a suitable biofilter media for the removal of Ammonia gas from composting plant with moderate removal efficiency of $65-70 \%$. The advantages of mixing of rice husk with cattle manure included increasing the population of nitrifying bacteria to decrease acclimation time and to reducing chances for compaction and channeling in the filter media.

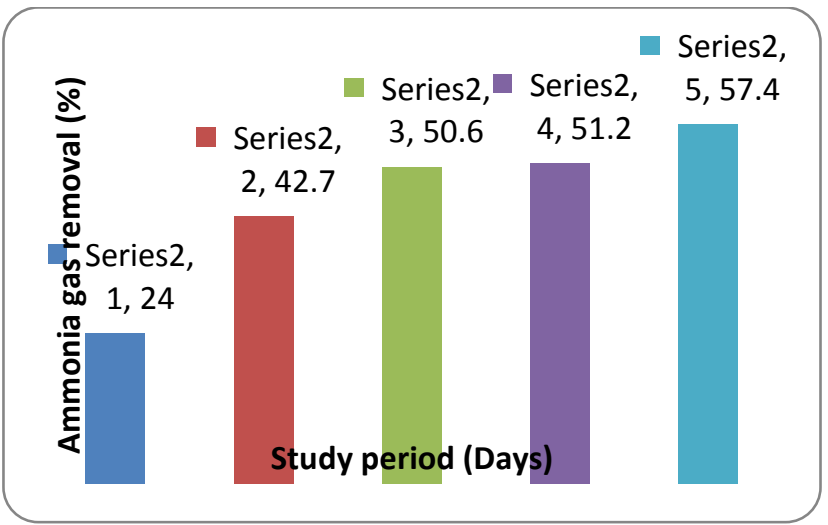

Figure 3: Efficiency of single layer in Ammonia gas removal

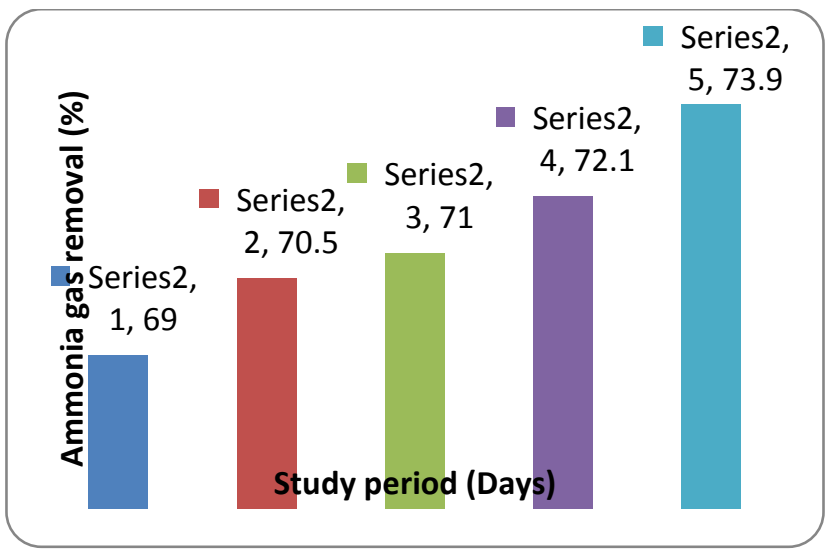

Figure 4: Efficiency of double layer in Ammonia gas removal

\section{CONCLUSION}

From this work, it can be concluded that,

- Removal efficiency for single layer bed depth of $20 \mathrm{~cm}$ was found to be $61.5 \%$ and for double layer bed depth of $40 \mathrm{~cm}$ was found to be $71.45 \%$. It was observed that as the bed depth of the filter media increases the removal efficiency of the biofilter increases 
- $\quad$ The nitrate concentration increased by $69.2 \%$ due to the conversion of nitrites to nitrates

\section{ACKNOWLEDGEMENT}

Authors express sincere thanks to Mr. Harish M. R Plant in-charge and Staff of Municipal Compost Plant, work Vidyaranyapuram, Mysuru for permitting and helping us

\section{REFERENCES}

[1] Chen Ying-xu, Yin Jun and Fang Shi, 2004, Biological removal of air loaded with a hydrogen sulphide and Ammonia mixture, Journal of Environmental Sciences, Vol. 16, No. 4, pp. 656-661

[2] Estela Pagans , Xavier Font, Antoni S'anchez, 2006, Emission of volatile organic compounds from composting of different solid wastes: Abatement by biofiltration, Journal of Hazardous Materials, Vol. B 131, pp. 179-186

[3] E. Kalingan, Chung-Min Liao, Jein-Wen Chen, and Szu-Chieh Chen, 2004, Microbial Degradation of Livestock-Generated Ammonia Using Biofilters at Typical Ambient Temperatures, Vol. B 39, No. 1, pp. $185-198$

[4] Estela Pagans, Xavier Font, Antoni Sanchez, 2005, Biofiltration for Ammonia removal from composting exhaust gases, Chemical Engineering Journal, 113, pp. 105-110

[5] Guillermo Baquerizo , Juan P. Maestre c, Takeyuki Sakumab, Marc A. Deshusses , Xavier Gamisans , David Gabriel , Javier Lafuente, 2005, A detailed model of a biofilter for Ammonia removal: Model parameters analysis and model validation, Chemical Engineering Journal, 113, pp. 205-214

[6] Ji - Hyung Hong, Reduction of Ammonia Emissions from Composting by Closed Bed Woodchips Biofilter, American Journal of Environmental Sciences, Vol. 8, pp. 540-742

[7] Kunwar D. Yadav, Vinod Tare and M. Mansoor Ahammed, 2008, Vermicompost as biofiltration media to control odor from human feces, Global Journal of Environmental Research, Vol. 2, No. 1, pp. $18-22$

[8] Melvin M. Galera, Wook-Jin Chung and Suk-Il Son, Biofiltration of Ammonia-, Hydrogen sulfide- and Toluene-contaminated Air stream with a Novel Rock wool-Compost Packing Media, pp.1- 14

[9] MR Shahmansouri, H Taghipour, B Bina, H Movahedian, 2005 , Biological Removal of Ammonia from Contaminated Air Streams Using Biofiltration System, Iranian Journal Env. Health Science Engg., Vol. 2, No. 2, pp. 17-25

[10] Ming-Shean Chou and Chia-Hsi Wang, 2007, Treatment of Ammonia in Air Stream by Biotrickling Filter, Aerosol and Air Quality Research, Vol. 7, No. 1, pp. 17-32

[11] Premkumar. R and Krishnamohan, Tamilnadu, 2013, Biological Elimination of Volatile Hydrogen Sulphide compounds in Biofilters, International Journal of ChemTech Research,India, ISSN : 0974-4290, Vol. 5, No. 1, pp. 56-64

[12] R.E. Nicolai and K.A. Janni, 2001, Biofilter media mixture ratio of wood chips and compost treating swine odors, Water Science and Technology, Vol. 44, No. 9, pp. 261-267

[13] Thakur Prabhat Kumar, Rahul, Mathur Anil Kumar and Balomajumder Chandrajit, 2011, Biofiltration of Volatile Organic Compounds (VOCs) - An Overview, Research Journal of Chemical Sciences, Vol. 1, No. 8, pp. 83-92

[14] Thaniya Kaosol and Nutthawut Pongpat, 2011, Biofilter Treating Ammonia Gas Using Agricultural Residues Media, World academy of Science Engineering and Technology, 105, pp 586-590
Biofilter media comprising the cattle manure and rice husk was found to be effective in converting Ammonia gas to Nitrate by absorbing from air stream. in carrying out this work. We extend our sincere thanks to all who directly and indirectly helped to carry out this 